\title{
Metallurgical Response of an AISI 4140 Steel to Different Plasma Nitriding Gas Mixtures
}

\author{
Adão Felipe Oliveira Skonieski*, Giovanni Rocha dos Santos ${ }^{\text {a }}$,
}

Thomas Karl Hirsch $^{\mathrm{b}}$, Alexandre da Silva Rocha ${ }^{\mathrm{a}}$

\author{
${ }^{a} P P G E 3 M$, Universidade Federal do Rio Grande do Sul - UFRGS, Av. Bento Gonçalves, 9500, \\ CEP 91501-970, Porto Alegre, RS, Brazil \\ ${ }^{\mathrm{b} S t i f t u n g}$ Institut für Werkstofftechnik - IWT, Badgasteiner Str. 3, 28359-Bremen, Germany
}

Received: August 14, 2012; Revised: January 7, 2013

\begin{abstract}
Plasma nitriding is a surface modification process that uses glow discharge to diffuse nitrogen atoms into the metallic matrix of different materials. Among the many possible parameters of the process, the gas mixture composition plays an important role, as it impacts directly the formed layer's microstructure. In this work an AISI 4140 steel was plasma nitrided under five different gas compositions. The plasma nitriding samples were characterized using optical and scanning electron microscopy, microhardness test, X-ray diffraction and GDOES. The results showed that there are significant microstructural and morphological differences on the formed layers depending on the quantity of nitrogen and methane added to the plasma nitriding atmosphere. Thicknesses of 10,5 and $2.5 \mu \mathrm{m}$ were obtained when the nitrogen content of the gas mixtures were varied. The possibility to obtain a compound layer formed mainly by $\gamma$ - $\mathrm{Fe}_{4} \mathrm{~N}$ nitrides was also shown. For all studied plasma nitriding conditions, the presence of a compound layer was recognized as being the responsible to hinder the decarburization on the steel surface. The highest value of surface hardness - $1277 \mathrm{HV}$ - were measured in the sample which were nitrided with $3 \mathrm{vol} . \%$ of $\mathrm{CH}_{4}$.
\end{abstract}

Keywords: plasma nitriding, mechanical properties, surface composition

\section{Introduction}

Nitriding is a very useful method to improve tribological and corrosive properties of iron-alloy components ${ }^{1,2}$. The aim of the nitriding processes applied to iron-based alloys is to introduce and diffuse atomic nitrogen into the surface of these metallic materials to improve wear and corrosion resistance. The nitrided layers in steels are usually composed of a compound layer formed by iron-(carbo)-nitrides and a diffusion zone. The compound layer (white layer) is found at the surface with a thickness of some micrometers. In the diffusion zone the nitrogen atoms can be interstitially dissolved or precipitated as iron-(carbo-)nitrides, and most probably as (carbo-)nitrides of the main alloying elements ${ }^{3,4}$.

The composition and thickness of the nitrided layers strongly depends on the steel type. High alloyed steels, for example, exhibit high hardness due to dispersed alloy nitrides in the matrix and high surface residual stresses are generated in the compound and diffusion zones for these steels, which are the result of chemical composition gradients, stress fields around precipitates, volume changes and thermal effects ${ }^{4}$. In the case of low alloyed steels, the diffusion layer does not reach hardness values as high as the obtained when nitriding tool steels, for example ${ }^{5}$. The compound layer plays the most important role against wear, and the diffusion layer has a secondary role, therefore for low alloyed steels to reach the correct morphology and phase composition of the compound layer is one of the main tasks to be accomplished.

The selection of process parameters for a given application depends on several aspects ${ }^{6,7}$. High temperature

*e-mail: adao.skonieski@ufrgs.br increases diffusion rate, but lower temperatures should normally be preferred due to the possibility of maintaining appropriate core material toughness and decreased risk of over tempering. Gas pressure has low influence on the surface chemical composition but can be adjusted to promote better plasma penetration into holes, for example. The current density depends on several other parameters like part geometry, voltage and furnace geometry, which makes its control very difficult, but it should be kept to a minimum value to assure many plasma benefits ${ }^{8}$. Therefore, the major influence on the metallurgical properties of plasma nitrided low alloyed steels is played by the gas mixture, the temperature and time.

Once plasma nitriding allows the use of different kind of gas mixtures, this parameter should be explored as an alternative to achieve different properties. Therefore, in this investigation AISI 4140 steel samples were plasma nitrided under different gas compositions (as given in Table 2) with a constant temperature of $500{ }^{\circ} \mathrm{C}$. Proportions of nitrogen, hydrogen and methane in the nitriding atmosphere were varied. The samples were characterized concerning the chemical composition, roughness, microstructure and hardness to evaluate the response of the steel to the applied treatment.

\section{Material and Methods}

Samples with $30 \mathrm{~mm}$ of diameter and $8 \mathrm{~mm}$ of thickness were machined from hot rolled and normalized AISI 4140 steel rods (chemical composition of the samples is 
presented in Table 1). Then, the samples were submitted to the following heat treatment sequence in a furnace with controlled atmosphere achieving a final core hardness of 37 HRC: austenitization during 30 minutes in a temperature of $850{ }^{\circ} \mathrm{C}$, quenching in oil (oil temperature of $80{ }^{\circ} \mathrm{C}$ ) and tempering during 120 minutes in the temperature of $460{ }^{\circ} \mathrm{C}$. Prior to the nitriding process, samples flat faces were sandpaper ground in a sequence with increasing mesh (\#120, \#400, \#600, \#1000) and then polished with diamond paste with abrasive size of $3 \mu \mathrm{m}$.

Plasma nitriding was carried out in a $0.3 \mathrm{~m}^{3}$ plasma nitriding furnace (Figure 1) equipped with a DC-pulsed power supply and a wall heating system. In the treatment of the samples, no furnace wall heating was used during the plasma nitriding process. The samples were degreased and cleaned with acetone in an ultrasonic bath before being placed into the furnace.

A plasma sputter cleaning of the samples surfaces was carried out using a hydrogen atmosphere of $70 \mathrm{~Pa}$ for 30 minutes and a voltage of $500 \mathrm{~V}$. After this first step, the specimens were constantly heated to reach the nitriding temperature, the used gas mixture was hydrogen and argon in a pressure of $300 \mathrm{~Pa}$. The temperature of the samples during the nitriding step was kept constant at $500{ }^{\circ} \mathrm{C}$ and the total pressure at $300 \mathrm{~Pa}$ for all the runs. The auxiliary heating system of the chamber was not used during the experiments, meaning the heat input was only due to ion bombardment. For the different experiments the gas mixtures were varied as presented in Table 2 . The nitriding time was fixed to 6 hours, except for the sample $5 \mathrm{~N}_{2}-2 \mathrm{~h}$ (treated during 2 hours).

The steps for the metallographic preparation were the following: cutting by a diamond saw, attaching of a wrought aluminum plate (indicated as metallic support in Figures 2 to 6), mounting in bakelite, griding with sandpaper from mesh \#120 to \#1000), polishing with diamond paste $3 \mu \mathrm{m}$ grain size, and finally, Nital $2 \%$ chemical etching. The characterization of the samples was done by optical microscopy to evaluate compound and diffusion layer microstructures. Microhardness profiles were performed in the cross section of the samples to obtain the total diffusion layer depth. In accordance with the ISO 4970 standard the total thickness of the thin surface layer is defined by the distance from the surface to the limit beyond which the hardness of the unaffected metal is reached. In order to compare the hardness when different compound layer thicknesses are present, the surface hardness was evaluated by Vickers, varying the applied loads from $0.025 \mathrm{~kg}$ to $0.5 \mathrm{~kg}$. The reason to vary the applied load is to get information concerning the hardness gradients in depths close to the surface, in order to complement the information given by the conventional cross section hardness profiles. A qualitative phase analysis was carried out by X-ray diffraction with $\mathrm{Cu}-\mathrm{K} \alpha$ radiation $(\lambda=0.154056 \mathrm{~nm})$ in the Brag-Brentano geometry, the $2 \theta$ angle was varied from $33^{\circ}$ to $50^{\circ}$ with a step size of $0.02^{\circ}$ and a time/step of 10 seconds. Chemical element depth profiles were obtained by means of a glow discharge optical emission spectroscopy (Leco GDS 750A GDOES equipment) for all nitriding conditions.

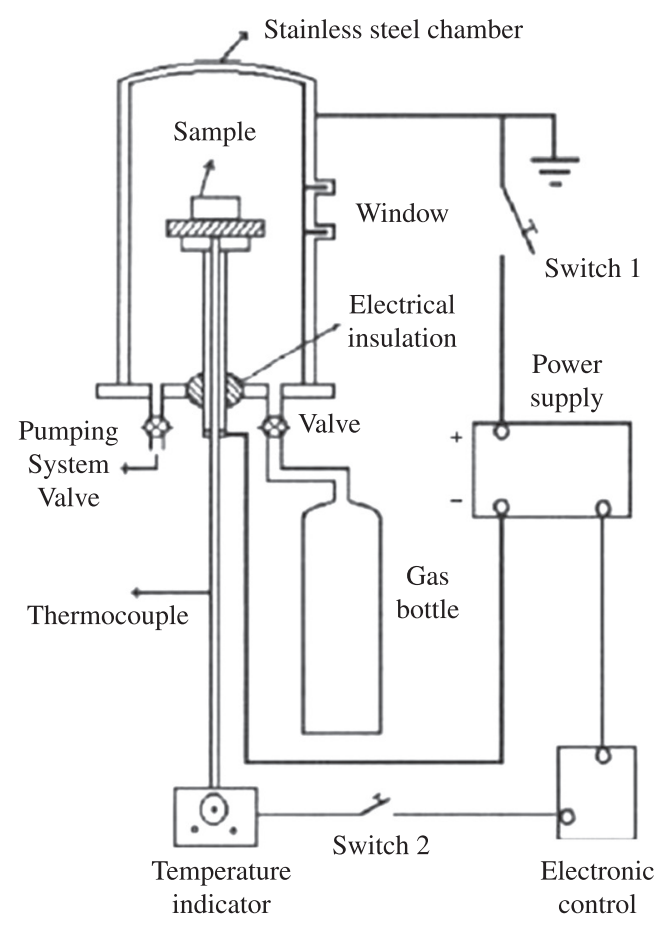

Figure 1. Schematic view of the plasma nitriding chamber with the samples distribution.

Table 1. Chemical composition of the AISI 4140 steel.

\begin{tabular}{cccccccccc}
\hline Element & $\mathbf{C}$ & $\mathbf{S i}$ & $\mathbf{M n}$ & $\mathbf{P}$ & $\mathbf{S}$ & $\mathbf{C r}$ & $\mathbf{M o}$ & $\mathbf{N i}$ & $\mathbf{F e}$ \\
\hline wt\% & 0.359 & 0.235 & 0.717 & 0.024 & 0.033 & 0.926 & 0.155 & 0.014 & 98.19 \\
\hline
\end{tabular}

Table 2. Gas mixtures for the nitriding batches.

\begin{tabular}{cccc}
\hline \multirow{2}{*}{ Sample } & & Gas Vol.\% & $\mathbf{C H}_{4}(\%)$ \\
\cline { 2 - 4 } & $\mathbf{N}_{2}(\%)$ & $\mathbf{H}_{2}(\%)$ & 3 \\
\hline $\mathrm{CH}_{4}-6 \mathrm{~h}$ & 70 & 27 & - \\
$70 \mathrm{~N}_{2}-6 \mathrm{~h}$ & 70 & 30 & - \\
$24 \mathrm{~N}_{2}-6 \mathrm{~h}$ & 24 & 76 & - \\
$5 \mathrm{~N}_{2}-6 \mathrm{~h}$ & 5 & 95 & - \\
$5 \mathrm{~N}_{2}-2 \mathrm{~h}$ & 5 & 95 & \\
\hline
\end{tabular}




\section{Results and Discussion}

\subsection{Microstructure, phase and chemical composition}

Figures 2 to 6 show the cross section of the samples after metallographic preparation on the left hand side and the corresponding chemical element depth profiles (GDOES) on the right hand side. The GDOES profiles were used to estimate the compound layer depth and these results are shown in the first column of Table 3 . In the second column of Table 3 the total layer depths are presented, resulting from the microhardness profiles discussed in the item 3.2.
The optical microscopy analysis and the GDOES profile for the sample $70 \mathrm{~N}_{2}-6 \mathrm{~h}$ ( $70 \mathrm{vol} . \% \mathrm{~N}_{2}$ in the gas mixture), as shown in Figure 2, clearly point out the formation of a compound layer with a thickness of about $10 \mu \mathrm{m}$. When changing the nitrogen content of the gas mixtures to $24 \mathrm{vol} . \%$ and to $5 \mathrm{vol} . \%$, thicknesses of $5 \mu \mathrm{m}$ and $2.5 \mu \mathrm{m}$, respectively, were estimated (Figures 3 and 4). As shown in Figure 5, however, when $\mathrm{CH}_{4}$ is added to the nitriding atmosphere of $70 \mathrm{vol} . \%$, a thinner white layer of about $4 \mu \mathrm{m}$ was obtained, which is approximately half of that obtained without methane addition (comparing Figure 2 with Figure 5). This effect is in accordance with Chen and Chang ${ }^{9}$ which have also published the same trend. As suggested by Chen et al,

Table 3. Summary of obtained results.

\begin{tabular}{|c|c|c|c|c|}
\hline Sample & $\begin{array}{c}\text { Compound Layer } \\
\text { Thickness }(\mu \mathrm{m})\end{array}$ & Total Layer Depth $(\mu \mathrm{m})$ & Phases on Surface & $\begin{array}{c}\text { Average Surface } \\
\text { Hardness (HV0.025)/ } \\
\text { Standard Deviation }\end{array}$ \\
\hline Polished & - & - & $\mathrm{Fe}-\alpha$ & $360 \pm 12.3$ \\
\hline $\mathrm{CH} 4-6 \mathrm{~h}$ & 4 & 350 & $\gamma^{\prime}, \varepsilon$ & $1277 \pm 16.5$ \\
\hline $70 \mathrm{~N} 2-6 \mathrm{~h}$ & 10 & 350 & $\gamma^{\prime}, \varepsilon$ & $1159 \pm 24.3$ \\
\hline $24 \mathrm{~N} 2-6 \mathrm{~h}$ & 5 & 350 & $\gamma^{\prime}, \varepsilon$ & $1053 \pm 28$ \\
\hline $5 \mathrm{~N} 2-6 \mathrm{~h}$ & 2.5 & 300 & $\gamma$ & $949 \pm 5.5$ \\
\hline $5 \mathrm{~N} 2-2 \mathrm{~h}$ & $<1$ & 150 & $\mathrm{Fe}-\alpha, \gamma$ & $705 \pm 10.4$ \\
\hline
\end{tabular}

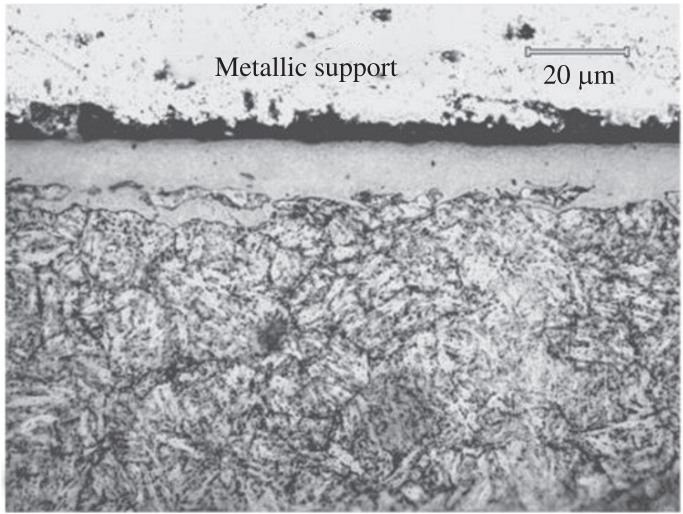

(a)

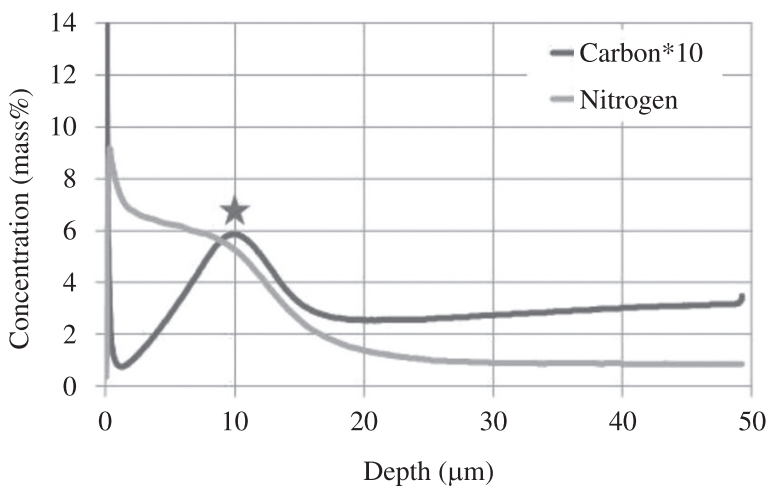

(b)

Figure 2. Sample $70 \mathrm{~N}_{2}-6 \mathrm{~h}$. In (a) photomicrography of the cross section of the sample and in (b) GDOES profile.

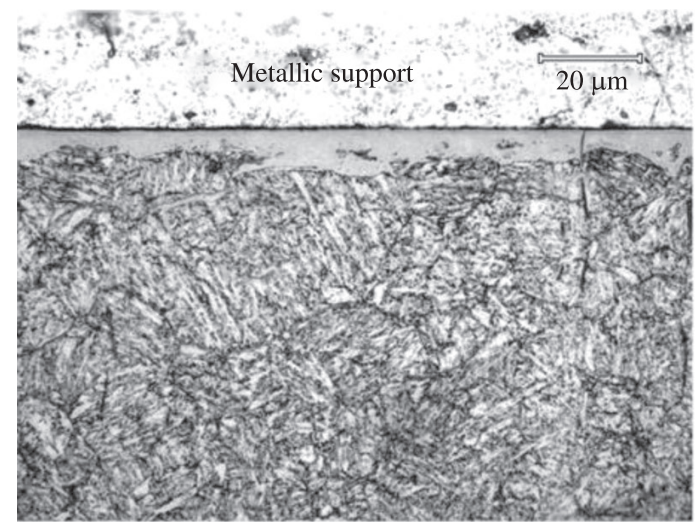

(a)

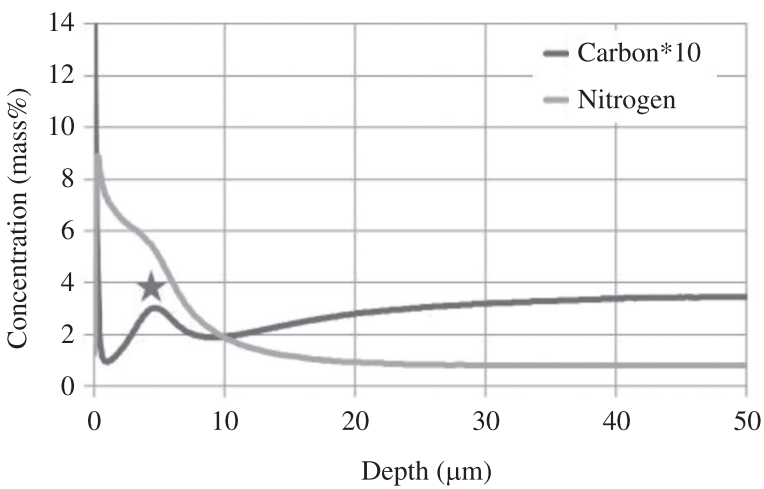

(b)

Figure 3. Sample $24 \mathrm{~N}_{2}-6 \mathrm{~h}$. In (a) photomicrography of the cross section of the sample and in (b) GDOES profile. 


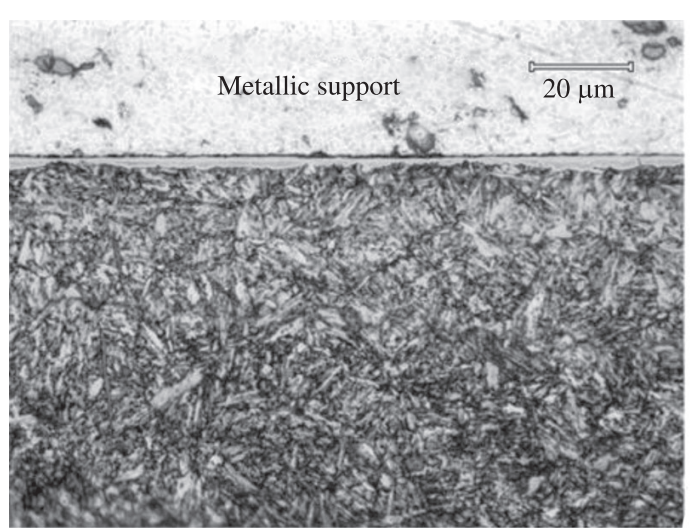

(a)

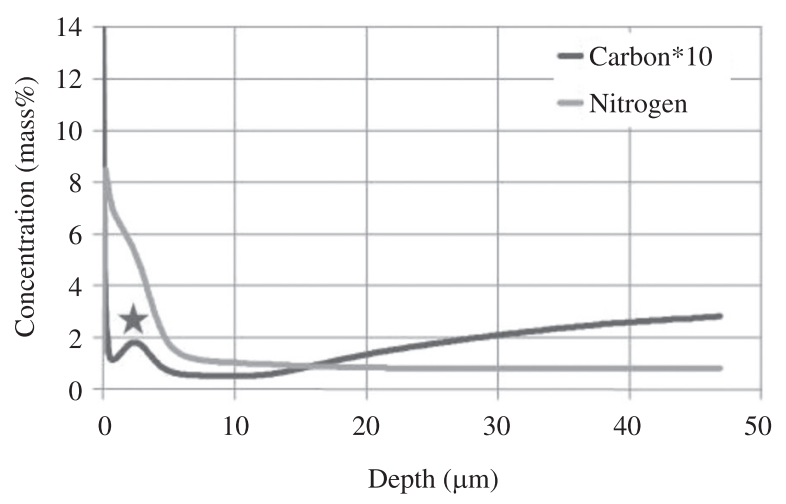

(b)

Figure 4. Sample $5 \mathrm{~N}_{2}-6 \mathrm{~h}$. In (a) photomicrography of the cross section of the sample and in (b) GDOES profile.

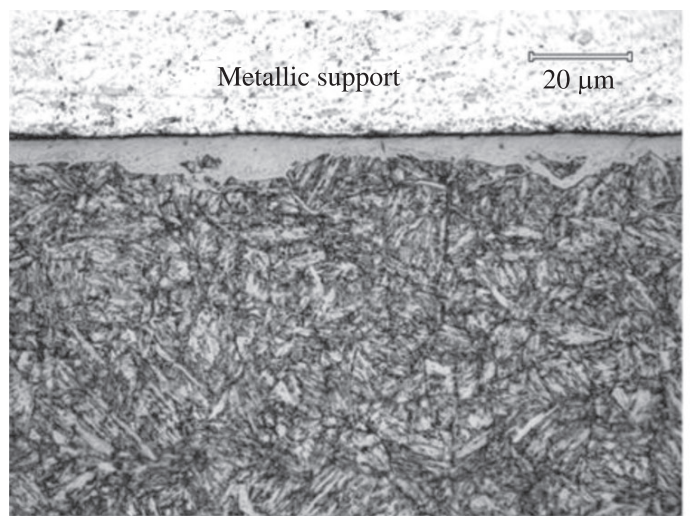

(a)

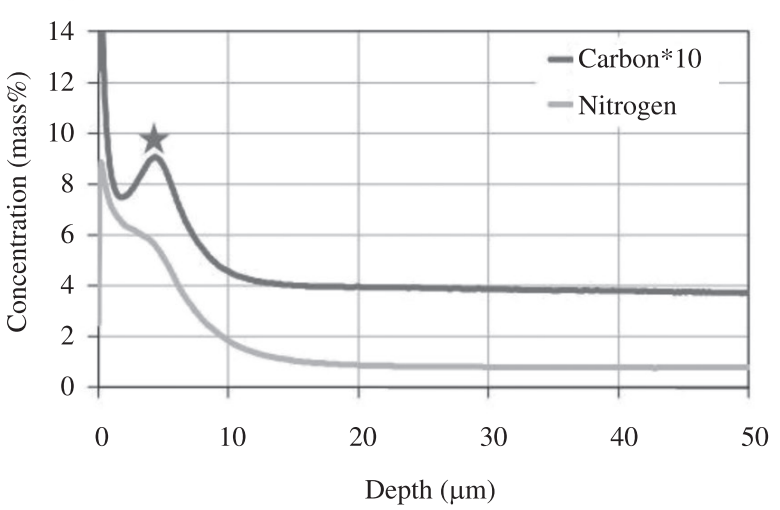

(b)

Figure 5. Sample $\mathrm{CH}_{4}-6 \mathrm{~h}$. In (a) photomicrography of the cross section of the sample and in (b) GDOES profile.

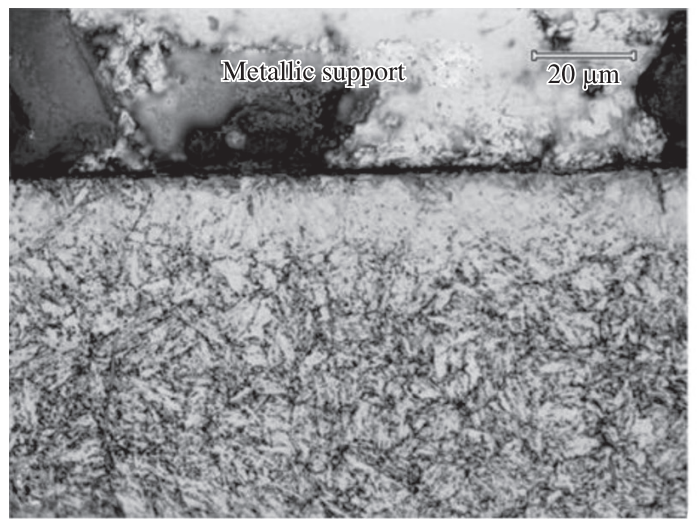

(a)

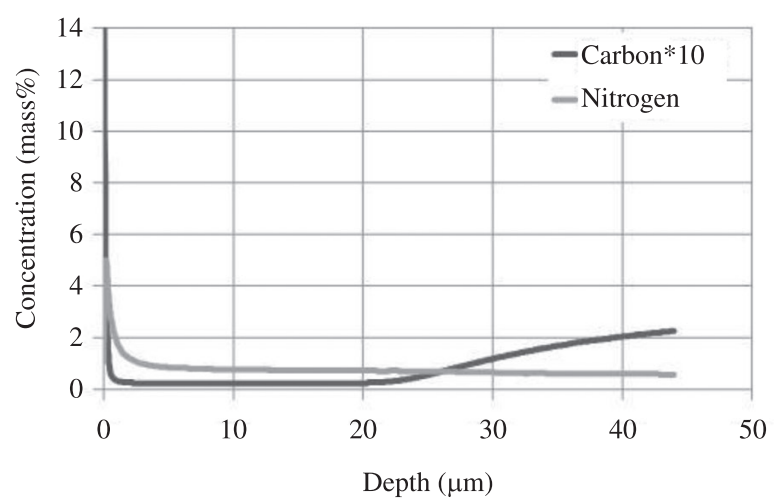

(b)

Figure 6. Sample $5 \mathrm{~N}_{2}-2 \mathrm{~h}$. In (a) photomicrography of the cross section of the sample and in (b) GDOES profile.

this happens probably due to a decrease in nitrogen activity in the atmosphere, similarly to the observations described by Slycke $^{10}$ in gas nitrocarburizing processes.

The specimens nitrided under the atmosphere with lower nitrogen content, $5 \mathrm{~N}_{2}-6 \mathrm{~h}\left(5 \mathrm{vol} . \% \mathrm{~N}_{2}\right)$, have also presented a compound layer on its surface. It was reported that this gas mixture can avoid the compound layer existence in other steels ${ }^{11}$. Taking into account this behavior of the AISI 4140 in comparison to other alloyed steels, an additional nitriding experiment was carried out with the same gas mixture ( 5 vol. $\% \mathrm{~N}_{2}$ ), decreasing the nitriding time from 6 to 2 hours. The aim was to verify whether a process time reduction would be able to avoid the compound layer formation.

Figure 6 shows the micrography of the sample nitrided with the reduced time and nitrogen content, condition $5 \mathrm{~N}_{2}-2 \mathrm{~h}$. It is clearly noticed that no compound layer was formed in the surface. In addition, analyzing the GDOES profiles for this condition, a $20 \mu \mathrm{m}$ decarburized layer 
is found as shown by the reduction of carbon content in the surface when compared to the carbon core content. Tier ${ }^{14}$ say that during nitriding, alloy carbides especially chromium carbides are make unstable in the nitrided layer. Hence, nitrogen replaces carbon in the carbide structure. Consequently, carbon is released and diffuses in both directions, i.e. to the surface and to the substrate core. The carbon diffusion towards the core forms the carbon-enriched zone below the nitrided layer. It was also discussed by Tier $^{14}$ which described the suggestions of Sun and Bell ${ }^{15}$ that because of a stress build-up in the nitrided zone, the carbon diffuses to the stressfree regions, i.e. to the surface and ahead of the nitrided case. The carbon diffused to the surface will be removed by sputtering and reactions with hydrogen, forming the observed decarburized zone.

For all other nitriding conditions, as shown in Figures 2 to 5 there was the formation of a compound layer as revealed by the higher content of nitrogen in the surface. The carbon content profile has a characteristic shape, due to the formation of the compound layer in the surface, a high content of nitrogen is seen and the carbon content is low, then as the distance from the surface increases, the carbon concentration becomes higher, forming a maximum located in the interface region between the compound layer and the diffusion zone. This maximum is marked with a star in Figures 2 to 5. The redistribution of carbon in the near surface region of plasma nitrided steels was discussed by several other authors ${ }^{9-12,14,15}$. This carbon peak concentration below the compound layer would be related to the formation of cementite, like precipitates in the grain boundaries ${ }^{16}$, which leads to lower toughness of the nitrided layer ${ }^{12,13}$.

Figure 7 presents the diffractograms for the different nitriding conditions and for an AISI 4140 quenched and tempered sample as reference. The iron peak is seen in the diffractogram for a non nitrided sample and for the $5 \mathrm{~N}_{2}-2 \mathrm{~h}$ condition only.

As seen in Figure 7, in the second and third diffractograms from bottom to top, the conditions $5 \mathrm{~N}_{2}-2 \mathrm{~h}$ and $5 \mathrm{~N}_{2}-6 \mathrm{~h}$ presented some remarkable differences between them. For the $5 \mathrm{~N}_{2}-2 \mathrm{~h}$ sample the iron peak is still seen, however, it is slightly shifted to the left. Peaks of $\gamma^{\prime}$ phase $\left(\mathrm{Fe}_{4} \mathrm{~N}\right)$ phase are also seen for this condition, this is an indication that the $\gamma^{\prime}$ began to be formed at the surface appearing as iron nitride clusters. This analysis agrees with the fact that a really thin compound layer could have been formed even for the $5 \mathrm{~N}_{2}-2 \mathrm{~h}$ condition.

As the nitriding time increases to 6 hours (condition $5 \mathrm{~N}_{2}-6 \mathrm{~h}$ ), formation of $\mathrm{Fe}_{4} \mathrm{~N}-\gamma^{\prime}$ monophase is clearly indicated by the $\gamma^{\prime}$ peaks and the very low intensity of the $\alpha$-iron peak. This analysis shows that the compound layer growth ( $\gamma^{\prime}$ monophase) is dependent on the nitriding time, once temperatures, gas mixtures and the other related variables were constant.

Now comparing the fourth and the fifth diffractograms, it is possible to see that both nitriding conditions, with intermediate nitrogen content $\left(24 \mathrm{~N}_{2}-6 \mathrm{~h}\right)$ and with high concentrations of nitrogen $\left(70 \mathrm{~N}_{2}-6 \mathrm{~h}\right.$ and $\left.\mathrm{CH}_{4}-6 \mathrm{~h}\right)$, have invariably generated the characteristic phases $\varepsilon\left(\mathrm{Fe}_{2-3} \mathrm{~N}\right)$ and $\gamma^{\prime}-\mathrm{Fe}_{4} \mathrm{~N}$, with some more $\varepsilon-\mathrm{Fe}_{2-3} \mathrm{~N}$ content for the $70 \mathrm{~N}_{2}-6 \mathrm{~h}$ condition. These results show that intermediate gas mixtures with concentrations above $24 \mathrm{vol} .-\% \mathrm{~N}_{2}$ are inefficient to promote the formation of $\gamma^{\prime}$ compound layers. The $24 \mathrm{vol} . \% \mathrm{~N}_{2}$ gas mixture is cited by Podgornik et al. ${ }^{17}$ as being a gas mixture that could produce pure $\gamma$ ' phase for the AISI4140 steel. However, a more recently research carried out by Corengia et al. ${ }^{18}$ (also using AISI 4140 steel, $500{ }^{\circ} \mathrm{C}$ and 24 vol. $\% \mathrm{~N}_{2}$ gas mixture) concluded that

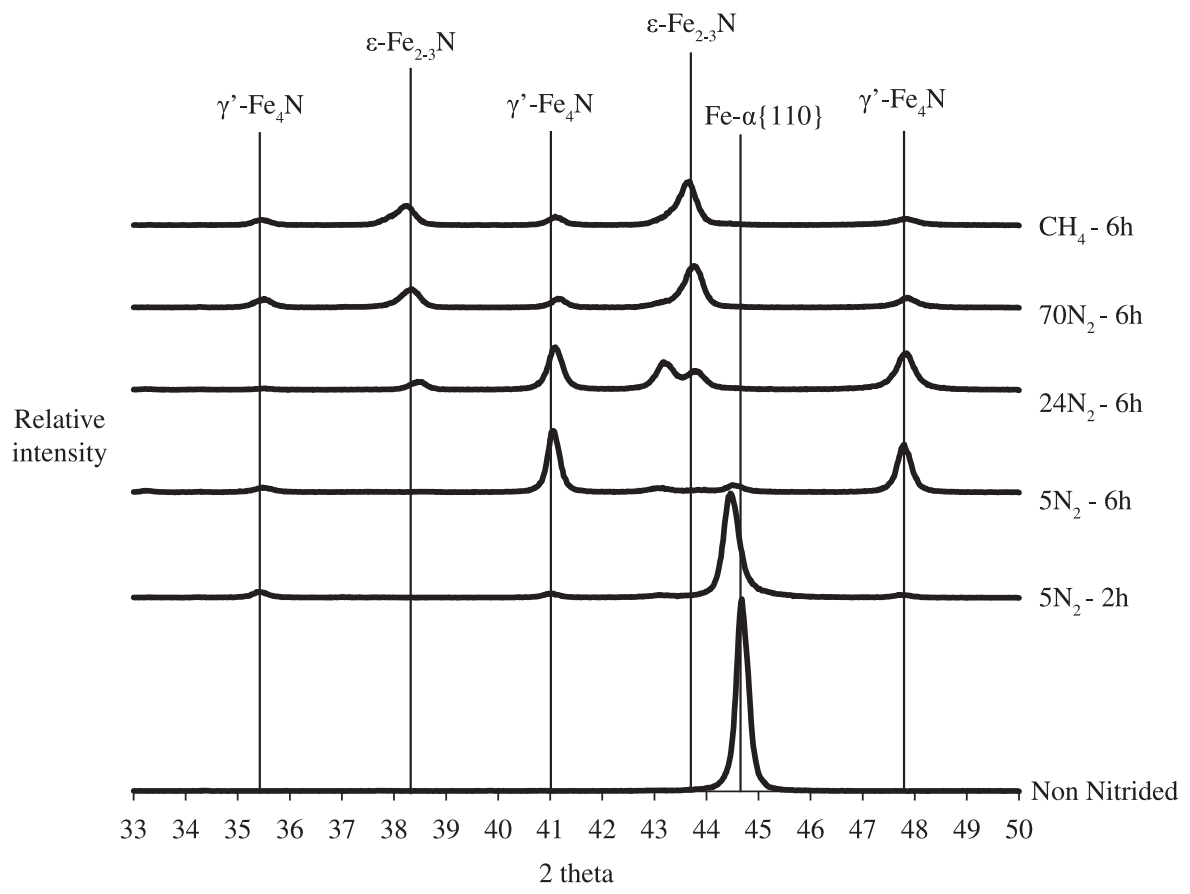

Figure 7. Diffraction lines of non-nitrided and nitrided samples. 
the $\gamma^{\prime}$ monophase appears for this steel only after 15 hours nitriding. The Corengia's ${ }^{18}$ results are in agreement with the findings from Podgornik et al. ${ }^{17}$ and also with the conclusions obtained in this study.

The last diffractogram (from bottom to top in Figure 7) shows the results for samples nitrided with 70 vol. $\% \mathrm{~N}_{2}$ gas mixture in which 3 vol. $\% \mathrm{CH}_{4}$ was added (condition $\mathrm{CH}_{4}-6 \mathrm{~h}$ ). The proportion of $\varepsilon$ increased if compared to the condition without Methane (fifth diffractogram from bottom to top), but the $\gamma$ ' phase was still present and, consequently, it was not possible to produce the monophase $\varepsilon$ on the surface of the samples. The results have shown that to obtain the pure $\varepsilon$ in the compound layer of plasma nitrided steels is more complex than the way mentioned by $\mathrm{O}^{\prime}$ Brien $^{19}$ and it's in accordance with other works that failed in the task of using this kind of gas to form such monophase $\mathrm{e}^{20,21}$. Moreover, is shown the amount of $\varepsilon$ phase in white layer (which is richer in $\mathrm{N}$ than $\gamma^{\prime}$ phase) depends directly on the $\mathrm{N} 2$ gas proportion. It occurs because there are more ionized $\mathrm{N}$ in the plasma atmosphere when more $\mathrm{N} 2$ is added into the chamber. The third column of Table 2 shows the main phases found for the different nitriding conditions.

\subsection{Microhardness}

The microhardness profile for each studied conditions is presented in Figure 8 (dashed line indicates the mean core hardness of the substrates). These graphics show the hardness of the nitrided layer as a function of depth and were obtained in the cross section of the samples. In terms

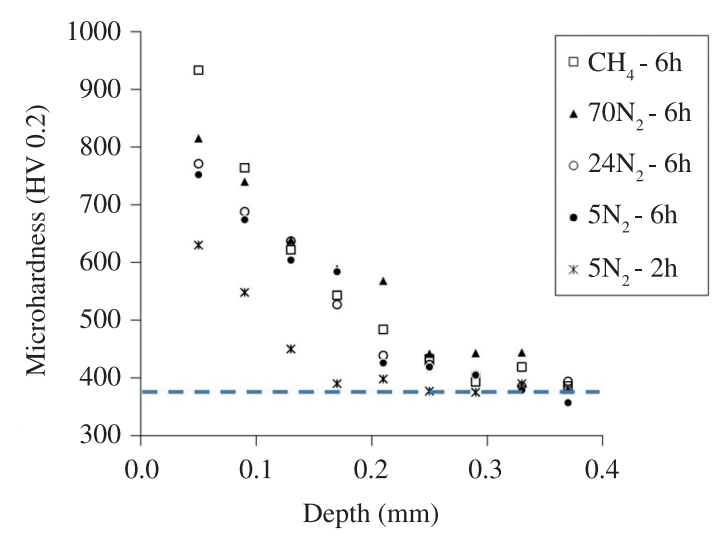

Figure 8. Hardness profile of nitrided samples.

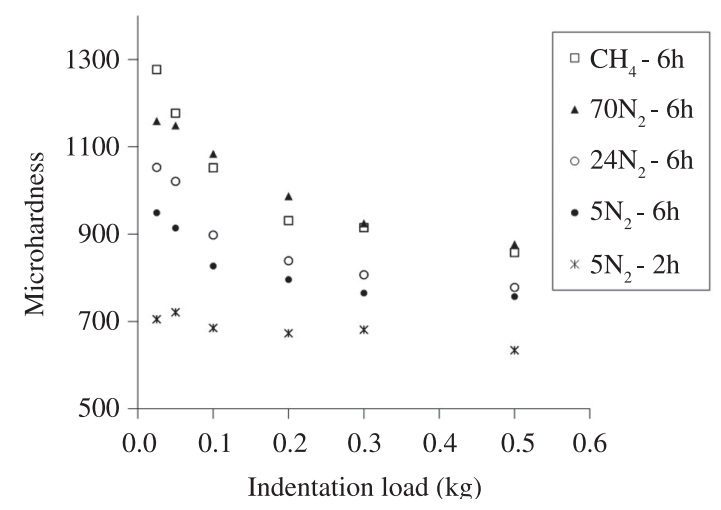

Figure 9. Surface hardness estimation of nitrided samples. of the total layer depth (see Table 2), conditions with and without methane $\left(\mathrm{CH}_{4}-6 \mathrm{~h}\right.$ and $\left.70 \mathrm{~N}_{2}-6 \mathrm{~h}\right)$ had the same measured value, approximately $350 \mu \mathrm{m}$, but on the other hand, differences were found for the hardness between these two conditions at a distance of $50 \mu \mathrm{m}$ from the surface. The addition of methane in the nitriding atmosphere caused an increase in hardness of about $120 \mathrm{HV}$ compared to the condition without methane addition.

Figure 9 shows the Vickers surface hardness as a function of the applied loads for all the studied conditions. The obtained surface hardness values are summarized in the Table 2. The observed higher hardness for the condition $\mathrm{CH}_{4}$ 6 h obtained in the microhardness profiles is confirmed by the surface microhardness measurements with different loads (Figure 9), where the estimated surface hardness values were $1277 \mathrm{HV}$ and $1159 \mathrm{HV}$ for the $\mathrm{CH}_{4}-6 \mathrm{~h}$ and $70 \mathrm{~N}_{2}-6 \mathrm{~h}$ nitriding conditions, respectively.

The nitriding conditions $24 \mathrm{~N}_{2}-6 \mathrm{~h}$ and $5 \mathrm{~N}_{2}-6 \mathrm{~h}$ led to a surface hardness values of $1053 \mathrm{HV}$ and $949 \mathrm{HV}$, and diffusion layer depths of about $350 \mu \mathrm{m}$ and $300 \mu \mathrm{m}$, respectively. When comparisons are done between these three nitriding conditions, $70 \mathrm{~N}_{2}-6 \mathrm{~h}, 24 \mathrm{~N}_{2}-6 \mathrm{~h}$ and $5 \mathrm{~N}_{2}-6 \mathrm{~h}$, in terms of microhardness profiles, as well as in terms of surface hardness, the behavior is as expected, the higher the nitrogen content in the gas mixture the higher the hardness of the obtained layers. The sample $5 \mathrm{~N}_{2}-2 \mathrm{~h}$ led to the shallowest diffusion zone obtained in this study $(150 \mu \mathrm{m})$ and to the lowest hardness level $(705 \mathrm{HV})$. As expected for this kind of steel, without compound layer formation lower hardness levels are achieved.

\section{Conclusions}

The results presented in this investigation have shown that by varying gas mixtures is possible to obtain compound layers for an AISI 4140 steel with significant different microstructural and mechanical properties.

The tested nitriding conditions with very low amount of nitrogen ( 5 vol.\%) lead to tougher nitriding layers. For this condition with 2 hours of nitriding time no continuous compound layer has been formed, which took to very low hardness values compared to the other nitriding conditions, since only a diffusion layer has been observed. However when the time was increase to 6 hours, a continuous compound layer of $5 \mu \mathrm{m}$ was found being formed by $\gamma$ ' nitrides only. By increasing the amount of nitrogen, to an intermediate level, as 24 vol\% of nitrogen, then a relatively thick compound layer of $\gamma^{\prime}$ and $\varepsilon$ nitrides is formed, but with still higher amounts of $\gamma^{\prime}$ than $\varepsilon$.

Nitrogen concentrations of $70 \mathrm{vol} \%$ took to an increase of compound layer hardness, amount of $\varepsilon$ nitrides, but also to less tougher layers. However when methane was added to this gas mixture, a thinner layer was formed which presented higher amounts of the $\varepsilon$ phase and showed the highest hardness among all plasma nitriding conditions tested.

\section{Acknowledgements}

The authors would like to thanks the Brazilian agencies CNPq, CAPES and FAPERGS for the financial support of the project, and Dr. Thomas Hirsch for the GDOES measurements done at IWT in Germany. We also would like to thanks our young researches João Paulo Vieira Bittencourt e Marcelo Munhoz Reffatti which had active collaboration in this work. 


\section{References}

1. Llanes Leyva CA, Godoy C, Bozzi AC and Wilson JCAB. Ultralow carbon (ULC) steel modified by triode plasma nitriding and PVD coating: Effects on micro-abrasive wear behavior. Surface and Coatings Technology. 2011; 206:1796-1808. http://dx.doi. org/10.1016/j.surfcoat.2011.08.021

2. Basu A, Majumdar JD, Alphonsa J, Mukherjee S and Manna I. Corrosion resistance improvement of high carbon low alloy steel by plasma nitriding. Materials Letters. 2008; 62:3117-3120. http://dx.doi.org/10.1016/j.matlet.2008.02.001

3. Wolfart M, Rocha AS, Strohaecher TR and Hirsch TK. Nitretação Ionica de Aço Ferramenta para Trabalho a Frio ABNT D6. In: Technical Conf. Wire Technology; 1996; São Paulo. São Paulo: ABM; 1996. p. 303.

4. Akbari A, Mohammadzadeh R, Templier C and Riviere JP. Effect of the initial microstructure on the plasma nitriding behavior of AISI M2 high speed steel. Surface and Coatings Technology. 2010; 204:4114-4120. http://dx.doi.org/10.1016/j. surfcoat.2010.05.042

5. Krauss G. Steels: Processing, Structure and Performance. ASM American Society for Metals; 2005. p. 1-559.

6. Tier MAD. Avaliação da Resistência ao Desgaste do Aço AISI M2 Nitretado a Plasma. [Tese]. Porto Alegre: Universidade Federal do Rio Grande do Sul; 1998. p. 1-138.

7. Ochoa EA, Figueroa CA, Alvarez F. The Influence of the ion current on plasma nitriding process. Surface and Coatings Technology. 2005; 2165-2169. http://dx.doi.org/10.1016/j. surfcoat.2004.09.004

8. Edenhofer B. Progress in the control of plasmanitriding and -carburizing for better layer consistency and reproducibility. In: Proceedings of the 6th International Conference on Plasma Surface Engineering; 1998; Garmisch-Partenkirchen, Germany. Garmisch-Partenkirchen; 1999. p. 257-259.

9. Chen F-S and Chang C-N. Effect of $\mathrm{CH} 4$ addition on plasma nitrocarburizing of austenitic stainless steel. Surface and Coatings Technology. 2003; 173:9-18. http://dx.doi. org/10.1016/S0257-8972(02)00842-3

10. Slycke J, Sproge L and Agren J. Nitrocarburizing and the Ternary Fe-N-C Phase-Diagram. Scandinavian Journal of Metallurgy. 1988; 17:122-126.

11. Rocha AS, Strohaecker TR and Hirsch T. Effect of different surface states before plasma nitriding on properties and machining behavior of M2 high-speed steel. Surface and
Coatings Technology. 2003; 165:176-185. http://dx.doi. org/10.1016/S0257-8972(02)00768-5

12. Tier M, Dos Santos AV, Kuhnen CA, Strohaecker TR and Krause JC. A study of grain boundary precipitation during plasma nitriding of steel. In: Proceedings of the 5th International Conference on Surface Modification Technologies; 2001; Indianapolis, USA. Materials Park: ASM International; 2002. p. 225-231.

13. Rocha AS, Strohaecker TR, Tomala V and Hirsch T. Microstructure and residual stresses of a plasma-nitrided M2 tool steel. Surface and Coatings Technology. 1999; 115:24-31. http://dx.doi.org/10.1016/S0257-8972(99)00063-8

14. Kwietniewski C, Fontana W, Moraes C, Rocha AS, Hirsch $\mathrm{T}$ and Reguly A. Nitrided layer embrittlement due to edge effect on duplex treated AISI M2 high-speed steel. Surface and Coatings Technology. 2004; 179:27-32. http://dx.doi. org/10.1016/S0257-8972(03)00795-3

15. Y. Sun T. Bell, Plasma Surface Engineering of low alloy steel. Material Science Engineering: A. 1991; 140:419-434. http:// dx.doi.org/10.1016/0921-5093(91)90458-Y

16. Tier MAD, Kieckow F, Strohaecker TR, Rocha AS, Santos $\mathrm{JF}$ and Bell T. Estudo do perfil de carbono na camada nitretada do aço AISI M2. Tecnologia em Metalurgia e Materiais. 2007; 4:6-11. http://dx.doi.org/10.4322/ tmm.00402002

17. Podgornik B, Vizintin J, Wanstrand O, Larsson M and Hogmark S. Wear and friction behaviour of duplex-treated AISI 4140 steel. Surface and Coatings Technology. 1999; 120-121:502-508. http://dx.doi.org/10.1016/S0257-8972(99)00417-X

18. Corengia P, Ybarra G, Moina C, Cabo A and and Broitman E. Microstructural and topographical studies of DC-pulsed plasma nitrided AISI 4140 low-alloy steel. Surface and Coatings Technology. 2005; 200:2391-2397. http://dx.doi.org/10.1016/j. surfcoat.2005.01.060

19. O'Brien JM and Goodman D. Plasma (Ion) Nitriding. In: ASM Handbook. ASM; 1991. v. 4: Heat Treating, p. 420-424.

20. Lee I. Post-oxidizing treatments of the compound layer on the AISI 4135 steel produced by plasma nitrocarburizing. Surface and Coatings Technology. 2004; 188-189:669-674. http:// dx.doi.org/10.1016/j.surfcoat.2004.07.093

21. Tsujikawa M, Yamauchi N, Ueda N, Sone T and Hirose Y. Behavior of carbon in low temperature plasma nitriding layer of austenitic stainless steel. Surface and Coatings Technology. 2005; 193:309-313. http://dx.doi.org/10.1016/j. surfcoat.2004.08.179 